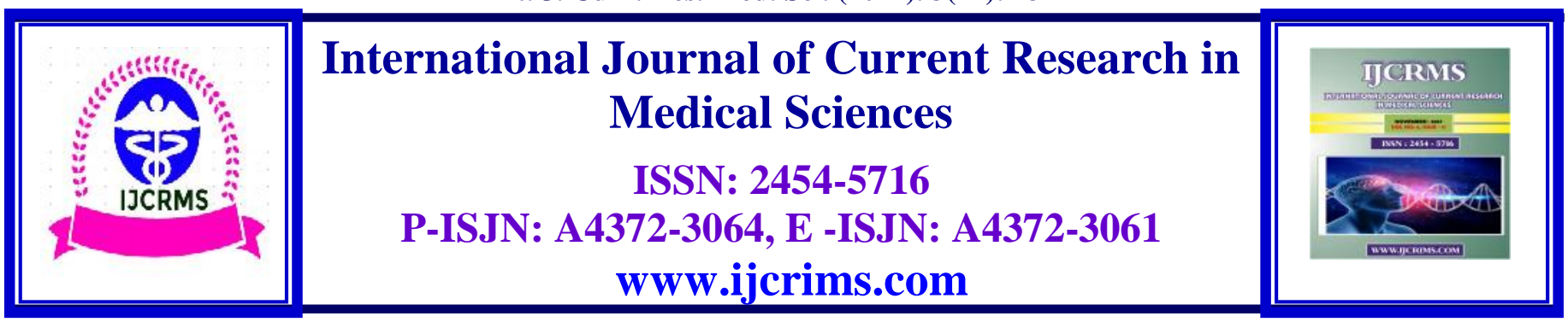

Case Report

Volume 3, Issue 11 -2017

DOI: http://dx.doi.org/10.22192/ijcrms.2017.03.11.005

\title{
Addicts' Viewpoint of the Reasons for Relapse (Case Study: Methadone Maintenance Treatment center of Assalouyeh)
}

\begin{abstract}
Ali Mohammadi
MA in Family Counseling, Lecturer Department of Psychology and Counseling, Payam Noor University, International Center of Assaluyeh, Iran
\end{abstract}

Keywords: Drug Addiction, Drug Abuse, Alcoholism, Relapse, Addict, MMT.

\section{Introduction}

This study aimed at identifying the reasons for relapsing into using drugs, identifying the differences in the reasons for relapse and addiction in terms of the narcotic substance used or the educational level variable.
According to previous research, the table below is a summary of the common changes that happen to our thinking, attitudes and behaviour in recovery that has led many of us in recovery to use drugs again.

\section{Relapse Warning Signs}

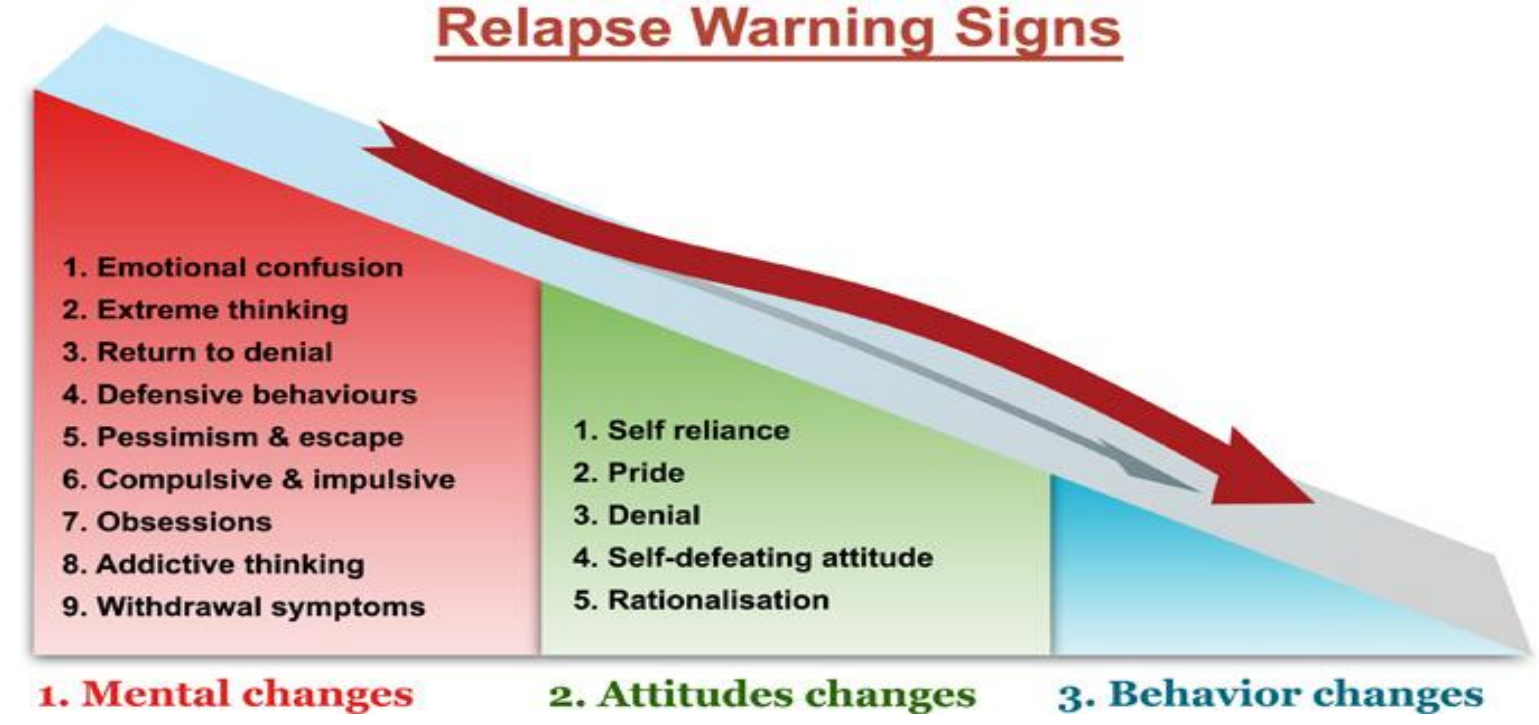

\section{Materials and Methods}

This is a cross sectional descriptive study that was performed on 100 clients admitted to addiction treatment center in Assaluyeh City, who had at least once a return to substance abuse and were selected using convenience sampling method. Data collection was performed by using structured interview and interview form in a single step. 
A questionnaire (Treatment File) divided into 4 sections is prepared. The first section contains personal data; the second contains information about the socio-economic level; the third section contains information on addiction; and the fourth contains information about relapsing. The research sample contains 100 relapsed addicts of the Assaluyeh Treatment Center. Data analysis and statistical was performed using SPSS software version 16 .

\section{Findings}

The most important results obtained are as follows:

The majority of the sample individuals have relapsed more than one time.

The important reasons for relapsing and going back to using drugs are:

-Incapability of facing troubles and pressures.

-Emergence of psychological problems (depression and anxiety).

-Family problems.

-Going back to mixing with addicts.

Statistically, the research sample displays no significant differences in the reasons for relapsing in terms of the educational level variable or the narcotic substance used except for alcohol and heroine.

\section{Discussion and Conclusion}

In general, prevention of risk factors for addiction relapse is a multi-dimensional program that with its implementation in future can prevent from relapse in the addicts under treatment and in addition to eliminating the dependence of physical with drug therapy, attention to the factors that were associated with an inability to quit is important. Also In order to prevent the recurrence of addiction, it is recommended to provide a specialist adviser and not allow the patient to socialize with addicts. Treatment programs should be more defined and strict during the first six months of recovery.tan.

\section{References}

Bondy,D.; Coello,T. Preventing relapse among inner-city recovering addicts. Research report, National Institute on Drug Abuse, New York, 1998, 246.

Krupitsky and et al. Naltrexone with or without fluoxetine for preventing relapse to heroin addiction in St. Petersburg, Russia. Journal of Substance Abuse Treatment. 2006. 31. 319328

Westhuizen M. A. V. Exploring the experience of chemically addicted adolescents regarding relapse after treatment. Master degree of Social Worker tez. University of South Africa. Nov 2007

\begin{tabular}{|c|l|}
\hline \multicolumn{2}{|c|}{ Access this Article in Online } \\
\hline & Website: \\
\hline & www.ijcrims.com \\
\hline Quick Response Code & $\begin{array}{l}\text { Subject: } \\
\text { Psychology and } \\
\text { Counseling }\end{array}$ \\
\hline
\end{tabular}

How to cite this article:

Ali Mohammadi. (2017). Addicts' Viewpoint of the Reasons for Relapse (Case Study: Methadone Maintenance Treatment center of Assalouyeh). Int. J. Curr. Res. Med. Sci. 3(11): 23-24.

DOI: http://dx.doi.org/10.22192/ijcrms.2017.03.11.005 